\title{
PENGARUH TERAPI VISUAL KARTU GAMBAR TERHADAP KEMAMPUAN KOMUNIKASI ANAK AUTIS DI PUSAT LAYANAN AUTIS KOTA BATAM TAHUN 2017
}

\section{(Effect of Visual Theraphy of Images Card to the Communication Autis Children in Autis Center Batam 2017)}

\author{
Utari CH Wardhani*) \\ Dosen STIKes Awal Bros Batam
}

\begin{abstract}
Visual therapy using image cards is one way to improve communication skills for autistic children. UNESCO in 2014 estimates that there are 35 million people with autism in the world. Indonesia, in 2013 and Director of Mental Health Development Ministry of Health had estimated the number of children with autism in Indonesia about 112 thousand with a range of 5-19 years. The phenomenon found in the Batam Autism Service Center, visual therapy with image cards has not been optimally performed on all children. Of the 18 people population sampled entirely, there is only 1 child who has good communication skills before therapy is given and the remaining 17 people have a poor ability. This study aims to determine the comparison before and after the visual therapy of the image card on the communication skills of autistic children in Batam Autis service center. This research uses Quasy Experiment method with time series design research. The sample in this research is 18 children with autism grouping stage of development of communication of children with autism stage three, that is The Early Communication Stage.Intervention done is giving visual therapy picture card every day schedule to every child counted 10 times therapy. The results before the visual therapy, the ability of good communication only about 6\% while the results of research after the visual therapy has increased to $61 \%$. In other words, the result of the research shows that there is an increase of communication ability $(p=0,05,95 \%$ CI). This study brings the conclusion that there is an increase in communication skills in children with autism at PusatLayananAutis Batam City. It is hoped that the application of visual therapy with image kart will be enhanced as this is one of the ways in improving the communication ability of autistic children, thus reducing barriers in communication and social interaction.
\end{abstract}

Keywords: Visual Therapy, Picture Cards, Communication, Autistic Children.

\section{PENDAhUluan}

Autisme merupakan gangguan perkembangan perpasif pada anak yang gejalanya muncul sebelum anak berumur 3 tahun.Perpasif berarti meliputi seluruh aspek perkembangan sehingga gangguan tersebut sangat luas dan berat, yang mempengaruhi anak secara mendalam.Gangguan perkembangan yang ditemukan pada autisme mencakup bidang interaksi sosial, komunikasi dan perilaku (Kementerian Kesehatan RI, 2013:13).

Pada hakikatnya seorang anak dinyatakan autisme jika mempunyai kelemahan pada tiga aspek yakni, komunikasi, sosial dan tingkah laku yang berulang (Hani'ah,2015). Anak dengan autisme dapat nampak dari gangguan perkembangan dalam bidang komunikasi, interaksi sosial, perilaku, emosi dan sensoris. Gangguan komunikasi pada autisme ditandai dengan tidak adanya kontak mata, terlambat bicara atau sama sekali belum dapat bicara, sulit untuk memulai percakapan dengan orang lain, mengulang kata-kata atau membeo, bicara dalam bahasa yang tidak dapat dimengerti, serta tidak memahami pembicaraan orang lain (Meranti,2013).

Sampai saat ini belum diketahui pasti penyebab autisme.Namun, ada dua faktor yang diyakini sebagai penyebab autisme, yaitu faktor genetik (keturunan) dan faktor lingkungan.Faktor genetik dipercaya mempunyai peran besar bagi munculnya autisme. Hasil penelitian menunjukkan bahwa kemungkinan 2 anak kembar identik mengalami autisme ialah $60-95 \%$, sedangkan kemungkinan bagi 
2 saudara kandung mengalami autisme hanyalah 2,5$8,5 \%$. Faktor lingkungan diduga sebagai penyebab autisme, dikarenakan adanya zat kimia (thimerosal) yang digunakan untuk mengawetkan vaksin mengandung merkuri, pada vaksin MMR yang diberikan rutin pada anak-anak yang mulai memunculkan gejala-gejala autisme setelahnya (Hani'ah,2015).

Menurut data 2014 dari Pemerintah Amerika Serikat, di negara tersebut sebanyak 1,5 persen anakanak atau satu dari 68 anak di Negara Paman Sam adalah autistik. Angka ini meningkat 30 persen dari 2012, yang memiliki perbandingan satu banding 88 anak. Dalam sebuah studi lainnya yang dilakukan tahun 2012 menyatakan bahwa sebanyak 1,1 persen penduduk di atas 18 tahun di Inggris adalah autis. Meski belum ada survei resmi tentang jumlah anak dengan autis di Indonesia, pada 2013 lalu Direktur Bina Kesehatan Jiwa Kementerian Kesehatan pernah menduga jumlah anak autis di Indonesia sekitar 112 ribu dengan rentang 5-19 tahun.Angka ini keluar berdasarkan hitungan prevalensi autis sebesar 1,68 per 1000 anak di bawah 15 tahun. Dengan jumlah anak usia 5-19 tahun di Indonesia sejumlah sekitar 66 juta menurut Badan Pusat Statistik, didapatlah angka 112 ribu tersebut (CNN Indonesia,2016).

Pusat Layanan Autis (PLA) adalah pusat layanan terpadu Dinas Pendidikan Kota Batam yang bertujuan untuk memberikan layanan terpadu dalam assesmen siswa, intervensi terpadu, pendidikan transisi serta layanan umum melalui pembinaan untuk anak autis.Berdasarkan hasil wawancara dan data yang diberikan oleh terapis atau tenaga pendidik di Pusat Layanan Autis. Anak dengan Autisme yang terdata sebanyak 74 orang siswa. Dalam proses observasi yang dilaksanakan pada tanggal 6 Febuari 2017, peneliti menemukan fenomena bahwa sebagian besar anak autis di Pusat Layanan Autis memiliki keterbatasan dalam bidang komunikasi dan interaksi sosial, seperti susah diajak berkomunikasi, tidak fokus dengan lawan bicara, suka mengulang perkataan atau tingkah laku serta bergumam bahkan berteriak tidak jelas. Penggunaan terapi kartu gambar di PLA sendiri belum efektif diterapkan, sehingga peneliti ingin melihat apakah ada dampak yang signifikan bila terapi kartu gambar dieterapkan secara efektif untuk meningkatkan kemampuan komunikasi pada anak autis di PLA Kota Batam.
Berdasarkan latar belakang di atas, peneliti tertarik untuk melakukan penelitian tentang efektifitas penggunaan media kartu gambar terhadap kemampuan komunikasi anak autis di Pusat Layanan Autis Kota Batam.

\section{TUJUAN PENELITIAN \\ 1. Tujuan Umum}

Untuk mengetahui pengaruh terapi visual kartu gambar terhadap kemampuan komunikasi anak penyandang autisme.

\section{Tujuan Khusus}

1. Mengetahui gambaran kemampuan komunikasi sebelum diberikan terapi visual kartu gambar pada anak autis

2. Mengetahui gambaran kemampuan komunikasi sesudah diberikan terapi visual kartu gambar pada anak autis.

3.Menganalisa pengaruh terapi visual kartu gambar dengan kemampuan komunikasi anak autis.

\section{METODE PENELITIAN}

Jenis penelitian yang peneliti gunakan dalam penelitian ini adalah penelitian kuantitatif dengan metode Quasy Eksperimen.Dengan rancangan penelitian Times Series Design, yaitu dengan pengukuran efek perlakuan yang dilakukan berulang berdasarkan perjalanan waktu.

Penelitian ini bertujuan untuk mengetahui pengaruh terapi visual terhadap komunikasi pada anak autis.Komunikasi sebagai variabel dependent yang diukur setelah diberikan perlakuan atau intervensi terapi visual beberapa kali.Pengukuran komunikasi diambil secara primer yaitu dengan melakukan observasi secara langsung menggunakan lembar observasi. Penelitian ini diukur secara berkala dari waktu ke waktu 
HASIL

Tabel 4.1

Karakteristik Responden Terapi Visual Di Pusat Layanan Autis Kota Batam Tahun 2017

\begin{tabular}{|c|c|c|c|}
\hline No & Usia & Frekuensi & $(\%)$ \\
\hline 1. & $2-6$ & 12 & $66 \%$ \\
\hline 2. & 7-11 & 4 & $22 \%$ \\
\hline \multirow[t]{3}{*}{3.} & $12-16$ & 2 & $11 \%$ \\
\hline & Total & 18 & $100 \%$ \\
\hline & \multicolumn{3}{|c|}{ enis kelamin } \\
\hline No & $\begin{array}{c}\text { Jenis } \\
\text { Kelamin }\end{array}$ & Frekuensi & $\%$ \\
\hline 1. & Laki-laki & 16 & $89 \%$ \\
\hline \multirow[t]{2}{*}{2.} & Perempuan & 2 & $11 \%$ \\
\hline & Total & 18 & $100 \%$ \\
\hline
\end{tabular}

Berdasarkan table 4.1 diketahui presenta seumur anak paling banyak yang menderita autis adalah pada rentang umur 2-6 tahun yaitu sebanyak 12 anak, dan didapatkan hasil angka anak autis terbanyak terjadi pada anak laki-laki yaitu $89 \%$ atau sebanyak 16 orang dari 18 orang total sample.

\section{Hasil Penelitian}

Berdasarkan hasil penelitian pada bulan April-Mei 2017, dengan jumlah responden sebanyak 18 orang, dengan judul penelitian Pengaruh Terapi Visual Kartu Gambar Terhadap Kemampuan Komunikasi Anak Autis di Pusat Layanan Autis Kota Batam Tahun 2017.

a. Distribusi Frekuensi Kemampuan Komunikasi Sebelum Dilakukan Terapi Visual Kartu Gambar.

Tabel 4.3

Distribusi FrekuensiKemampuan Komunikasi Sebelum Dilakukan Terapi Visual padaAnakAutis di PusatLayananAutis Kota Batamtahun 2017

\begin{tabular}{lccc}
\hline No. & $\begin{array}{c}\text { Kemampuan } \\
\text { Komunikasi } \\
\text { Sebelum } \\
\text { Terapi }\end{array}$ & Frekuensi & $\%$ \\
\hline 1. & Baik & 1 & $6 \%$ \\
2 & Tidak baik & 17 & $94 \%$ \\
& Total & 18 & $100 \%$ \\
\hline
\end{tabular}

b. $\mathbf{J}$
Berdasarkan tabel 4.3 diatas hasil analisa yang Yaitu sebanyak 17 dari total 18 anak tida berkomunikasi dengan baik, atau sebanyak (94\%).

b. Distribusi Frekuensi Kemampuan Komunikasi Dilakukan Terapi Visual Kartu Gambar.

Tabel 4.4

Distribusi Frekuensi Kemampuan Komunikasi

Dilakukan Terapi Visual pada Anak Autis di Pusa Autis Kota Batam tahun 2017

\begin{tabular}{lccc}
\hline No & $\begin{array}{c}\text { Kemampuan } \\
\text { Komunikasi } \\
\text { Sesudah Terapi }\end{array}$ & Frekuensi & \% \\
\hline 1. & Baik & 11 & $61 \%$ \\
2 & Tidak Baik & 7 & $39 \%$ \\
& Total & 18 & $100 \%$ \\
\hline
\end{tabular}

Berdasarkan tabel 4.4 diatas, didapatkan ha sebagian besar anak sudah mempunyai kemampuan yang baik.Yaitu sebanyak 11dari total 18 ana berkomunikasi dengan baik, atau sebanyak $61 \%$.

c. Distribusi Frekuensi Kemampuan Komunikasi Sebelum dan Sesudah Dilakukan Terapi Visual Kartu Gambar.

Tabel 4.5

Distribusi Frekuensi Rata-rata Peningkatan Kemampuan Komunikasi Sebelum dan Sesudah Diberikan Terapi Visual Kartu Gambar

Pada Anak Autis

\begin{tabular}{lcccc}
\hline Variabel & n & Mean & SD & p-Value \\
\hline Sebelum & 18 & 0.55 & 1.24722 & 0.000 \\
Sesudah & 18 & 4.88 & 1.45072 &
\end{tabular}

Berdasarkan tabel 4.4 diatas, didapatkan hasil analisa nilai mean atau nilai rata-rata kemampuan komunikasi anak autis sebelumya adalah 0,55 sedangkan nilai mean atau rata-rata kemampuan komunikasi anak autis setelah dilakukan terapi visual adalah 4,88.

Dengan menggunakan aplikasi SPSS, dilakukan uji statistic t-test dan diperoleh nilai signifikan 0,000 $(\rho=<0,05)$ dengan demikian $\mathrm{H} 0$ ditolak, hingga dapat disimpulkan bahwa ada Pengaruh dari Terapi Visual Kartu Gambar 
terhadap perubahan kemampuan komunikasi sebelum dan sesudah dilakukan pada anak autis di Pusat Layanan Autis Kota Batam.

\section{PEMBAHASAN}

a. Kemampuan Komunikasi Sebelum Dilakukan Terapi Visual

Berdasarkan hasil observasi sebanyak 10 kali didapatkan hanya 1 orang anak dari 18 orang yang mempunyai kemampuan komunikasi yang cukupbaik sebelum dilakukan terapi visual, atau dengan kata lain hanya 6\% sedangkan selebihnya memiliki kemampuan komunikasi yang kurang baik yaitu sebanyak $94 \%$ atau sekitar 17 orang anak yang memiliki kemampuan komunikasi yang tidak baik.

Autisme merupakan gangguan perkembangan fungsi otak yang kompleks dan bervariasi yang mengakibatkan otak tidak mampu berfungsi sebagaimana mestinya. Beberapa karakteristik yang menonjol pada anak autis ialah mengalami kesulitan dalam membina hubungan sosial , sulit berkomunikasi, sulit memahami emosi dan perasaan orang lain, menunjukkan perilaku yang repetitif, mengalami gangguan perilaku agresif dan hiperaktivitassekaligus gangguan sensoris serta mengalami perkembangan yang terlambat, tidak normal atau tidak seimbang (Hani'ah,2015).

Gangguan komunikasi pada anak autis merupakan faktor internal, karena autisme sendiri merupakan gangguan perpasif atau gangguan yang meliputi seluruh aspek perkembangan sehingga gangguan tersebut sangat berat dan luas, yang mempengaruhi anak secara mendalam. Gangguan perkembangan yang ditemukan pada autis memencakup bidang interaksi sosial, komunikasi dan perilaku (Kementerian Kesehatan RI, 2013;13). Strategi visual adalah sesuatu yang kita lihat untuk membantu komunikasi. Tujuan utama strategi visual adalah untuk mendukung pemahaman, karena strategi visual lebih mudah dipahami daripada informasi pendengaran. Strategi visual adalah strategi komunikasi yang lebih memfokuskan pada fungsi pengelihatan. Cara ini dilakukan dengan memberikan foto atau gambar yang dapat dipakai untuk memberi tahu anak mengenai aktifitas yang harus dilakukan. (Dian Nafi,2012).

Anak autis adalah pembelajar visual. Mereka kesulitan untuk berfikir abstrak sehingga sering kali komunikasi menjadi terhambat. Pemakaian strategi visual dengan menggunakan gambar, foto atau tulisan akan mampu mengatasi hambatan komunikasi ini. Melalui visualisasi, pemahaman anak terhadap konsep tertentu menjadi lebih kongkret daripada bahasa yang diucapkan. Selain itu, melalui visualisasi bisa mengajarkan anak mandiri, menjelaskan arti yang penting dari suara lain, meningkatkan pengertian anak terhadap lingkungan, menggunakan kekuatan visual yang dimiliki anak, dan dengan menggunakan gambar yang jelas bisa membuat anak lebih fokus. Pada akhirnya, bisa menurunkan frustasi dan ketakutan pada anak dalam melakukan komunikasi dengan orang lain (Dian Nafi,2012)

Penelitian ini sejalan dengan pernelitian yang dilakukan oleh Chairunnisa et.al (2012), dengan judul "Metode Dukungan Visual pada Pembelajaran Anak dengan Autisme " yang memaparkan bahwa dukungan visual body language berupa ekspresi wajah, menunjuk, memegang, menggerakkan tangan, menggelengkan kepala, menganggukkan kepala, membantu anak autis mendalam berkomunikasi.

Berdasarkan hasil penelitian, kemampuan komunikasi anak dapat meningkat dengan beberapa terapi lainnya selain metode terapi visual. Karena selain terapi visual, anak autis juga menjalani banyak tahap terapi lainnya, Namun terapi 
visual ini menurut teori dapat membantu menarik perhatian anak autis ketika diajak berkomunikasi oleh lawan bicara, karena anak autis lebih mudah tertarik dan lebih mudah memahami strategi terapi visual daripada informasi pendengaran (Dian Nafi, 2012).

c. Kemampuan Komunikasi Setelah Dilakukan Terapi Visual

Berdasarkan teori yang disampaikan oleh Dian Nafi,2012Terapi Visual atau Strategi visual adalah sesuatu yang kita lihat untuk membantu komunikasi. Tujuan utama strategi visual adalah untuk mendukung pemahaman, karena strategi visual lebih mudah dipahami daripada informasi pendengaran. Strategi visual adalah strategi komunikasi yang lebih memfokuskan pada fungsi pengelihatan. Cara ini dilakukan dengan memberikan foto atau gambar yang dapat dipakai untuk memberi tahu anak mengenai aktifitas yang harus dilakukan

Hal ini sejalan dengan penelitian yang dilakukan olehYufi Betty Febriatmika (2013) juga menunjukkan hasil bahwa penggunaan kartu gambar efektif dalam menangani masalah kognitif termasuk kemampuan komunikasi diperoleh presentase $90,9 \%$ atau lebih dari $75 \%$. Hal ini berarti kartu gambar yang digunakan dalam terapi terapi terhadap masalah kognitif pada anak autis dapat mengatasi kendala komunikasi dan persepsi yang dimiliki anak autis.

Sebelum dilakukan terapi visual kemampuan anak untuk melakukan komunikasi dianggap sangat kurang, selain tidak fokus anak juga terlihat tidak tertarik pada lawan bicara atau terapis.Hal ini disebabkan karena terapi visual mempunyai fungsi untuk membantu anak lebih fokus dalam berkomunikasi.Dari hasil yang didapat setelah dilakukan terapi visual kemampuan komunikasi anak dinilai lebih meningkat dari segi komunikasi non-verbal terutama pada kontak mata, atau visualisasi.

Berdasarkan hasil penelitian pada tabel 4.4 yang telah peneliti lakukan dalam pengolahan data menunjukkan 13 dari 18 orang menunjukkan kemajuan dalam berkomunikasi..

d. Pengaruh Terapi Visual Kartu Gambar Terhadap Kemampuan Komunikasi Anak Autis.

Bedasarkan hasil penelitian yang dilakukan pada tabel 4.6 dari 18 responden diketahui 11 orang anak mengalami peningkatan kemampuan komunikasi dari sebelumnya yang hanya 1 orang anak yang mempunyai kemampuan komunikasi cukup baik. Setelah dilakukan uji statistik t-testdan diperoleh nilai signifikan 0,000 $(\rho=<0,005)$ dengan demikian H0 ditolak, hingga dapatdisimpulkan bahwa ada Pengaruh dari Terapi Visual Kartu Gambar terhadap perubahan kemampuan komunikasi sebelum dan sesudah dilakukan pada anak autis di Pusat Layanan Autis Kota Batam.

Penelitian ini merupakan penelitian yang membandingkan kemampuan komunikasi anak autis sebelum dan sesudah dilakukannya terapi visual, dan dilakukan dalam satu kelompok intervensi.Hasil yang didapatkan adalah sekitar 55\% kemampuan komunikasi anak autis terjadi peningkatan, dari $6 \%$ menjadi $61 \%$. Hal ini sejalan dengan penelitian yang dilakukan Yufi Betty Ferbriatmika (2013) bahwa $75 \%$ kemampuan kognitif meningkat sehingga mengatasi kendala komunikasi anak autis.

Dari beberapa hasil yang telah dijelaskan maka dapat diketahui adanya dampak positif dari terapi visual menggunakan kartu gambar, karena kartu gambar mempunyai peranbesar dalam pengalihan focus ketertarikan anak autis dalam melakukan komunikasi. Berdasarkan uji statistik t-testdan diperoleh nilai signifikan $0,000 \quad(\rho=<0,05)$ dengan demikian Ha diterima dan $\mathrm{H} 0$ ditolak, hingga dapatdisimpulkan bahwa ada pengaruh dari 
Terapi Visual Kartu Gambar terhadap perubahan kemampuan komunikasi sebelum dan sesudah dilakukan pada anak autis di Pusat Layanan Autis Kota Batam.

Dari beberapa teori dan hasil penelitian terkait yang telah dipaparkan, maka dapat diketahui bahwa Terapi Visual Kartu Gambar mempunyai pengaruh pada peningkatan kemampuan komunikasi pada anak autis. Peneliti sendiri mengakui bahwa anak autis membutuhkan sesuatu yang dapat membantu fokusnya pada saat melakukan komunikasi. Kartu gambar adalah salah satu cara untuk membantu fokus anak saat diajak berbicara atau berinteraksi. Anak autis akan lebih mudah memahami apabila proses belajar disertai dengan gambar, karena melalui visualisasi pemahaman anak autis menjadi lebih meningkat daripada diajarkan hanya dengan suara tanpa melihat bentuk.

Hasil penelitian keseluruhan yang didapat peneliti adalah, dari 9 komponen kemampuan komunikasi (bicara, menulis, mendengar, membaca, menyentuh, kontakmata, ekspresiwajah, isyarat, dansikaptubuh) kemampuan yang paling meningkat adalah kemampuan kontak mata, dan kemampuan yang paling sulit meningkat adalah ekspresi wajah. Kemudian dari 9 komponen kemampuan komunikasi yang dinilai sebanyak 10 kali pertemuan didapatkan peningkatan kemampuan masing-masing anak berada dalam kategoribaik (di atas nilai 5) terjadi dalam pertemuan keenam dan seterusnya.

\section{KESIMPULAN}

Berdasarkanhasilpenelitiandanuraianp embahasan di bab-bab sebelumnya bahwapengaruhterapi visual padaanakautis di Pusat Layanan Autis Batam, yang didapatkan adalah sebagai berikut :

1. Karakteristik responden berdasarkan jenis kelamin yaitu sekitar $89 \%$ berjenis kelamin laki-laki atau 16 dari 18 orang anak.

2. Kararateristik responden berdasarkan usia, sebanyak $66 \%$ atau sekitar 12 orang anak berusia 2-6 tahun, $22 \%$ atau sekitar 4 orang anak berusia 7-11 tahun, dan 11\% anak atau sekitar 2 orang anak berusia 12-16 tahun.

3. Kemampuan komunikasi anak sebelum dilakukan terapi visual kartu gambar dalam persentase hanya sekitar $6 \%$ yang mampu berkomunikasi dengan baik sedangkan sisanya kurang mampu berkomunikasi dengan baik.

4. Kemampuan komunikasi anak sesudah dilakukan terapi visual kartu gambar didapatkan sekitar $61 \%$ anak sudah mampu berkomunikasi dengan baik, atau lebih tepatnya sekitar 11 orang dari 18 orang anak sudah memenuhi syarat dalam cara berkomunikasi yang baik.

\section{DAFTAR PUSTAKA}

Bety Febriatmika.Y. (2013). Penanganan Masalah Kognitif Pada Anak Autis Dengan Menggunakan Kartu Gambar.Skripsi trata satu, Universitas Muhammadiyah Surakarta, Surakarta.

Dhiki Y.M (2016). Kemampuan komunikasi dalam berintereaksi sosial anak autis.Universitas Negeri Yogyakarta.Yogyakarta.

Endro Priherdityo. (2016) Indonesia Masih 'Gelap' Tentang Autisme.

http://www.cnnindonesia.com/gaya-

hidup/20160407160237-255-

122409/indonesia-masih-gelap-tentangautisme/

Hani'ah, Munnal (2015). Kisah Inspiratif Anak Autis Berprestasi. Yogyakarta: DIVA Press.

Kementrian Kesehatan RI (2013). Pedoman Pelaksanaan Stimulasi,Deteksi,dan Intervensi Dini Tumbuh Kembang Anak di Tingkat Pelayanan Kesehatan Dasar. Jakarta:Kemenkesh RI

K.K Dharma (2015). Metodologi Penelitian Keperawatan. Jakarta:Rineka Cipta

Meranti, Tanti (2013). Psikologi Anak Autis. Yogyakarta : Relasi Inti Media

Nafi, Dian (2012).Bermain dan Belajar Bersama ABK-Autis. Yogyakarta:Familia

Nirahma Chairunnisa, Yuniar Ika (2012).Metode Dukungan Visual Pada Pembelajaran Anak 
Dengan Autisme. Univeritas Airlangga, Surabaya

Notoatmojo (2010).Metodologi Penelitian

Kesehatan. Jakarta: Rineka Cipta

Notoatmojo (2012).Metodologi penelitian kesehatan.Jakarta: Rineka Cipta

Rahayu,F. (2014). Kemampuan Komunikasi Anak Autis Dalam Interaksi Sosial, Yogyakarta

Wiratna Sujarweni,V (2015). Statitik Untuk Kesehatan. Yogyakatra : Gava Medika

Yahya, R.C (2012).Autisme-

Pengertian,Penyebab,Gejala,Ciri dan

Terapi. 